\title{
Possible large-scale sinistral displacement along the Great Glen Fault in Scotland
}

SIR, - In a recent paper Storetvedt (1974) has suggested that there may have been a late Caledonian (i.e. late Devonian) sinistral movement of $200-300 \mathrm{~km}$ along the Great Glen Fault. The evidence for this hypothesis is based on a comparison of palaeomagnetic data from Middle and Upper Old Red Sandstone lavas of Orkney and ?Lower Old Red Sandstone red beds of Caithness with corresponding data from Devonian sediments in south Norway. Storevedt states that his reconstruction is not at variance with evidence from the distribution of 'early granites, migmatites, metamorphic zones, new granites, etc.' on either side of the fault and claims that there is a valid correlation between the rocks of Caithness and those of Shetland east of the Walls Boundary Fault, which he accepts as the northward continuation of the Great Glen Fault. In his palaeogeographic reconstruction of the relative positions of the land areas of northern Britain prior to the 'large-scale post-Devonian sinistral displacement' along the fault (Fig. 2) he juxtaposes southern Shetland with Caithness.

Though the evidence from metamorphic and plutonic rocks for the direction of movement along the Great Glen Fault has been used with equal facility to demonstrate dextral or sinistral movement of varying magnitudes (see Kennedy, 1946; Garson \& Plant, 1972; Munro, 1973; Winchester, 1973), no attempt has been made to seek corroborative evidence from the Old Red Sandstone sediments lying astride the postulated northward extension of the fault in Caithness, Orkney and Shetland. Thus Storetvedt places the sediments of the southern Orcadian basin in virtual contact with the Old Red Sandstone of East Shetland, without considering either the stratigraphical or palaeogeographical implications. The Caithness/Orkney rocks consist of an impersistent basal ?Lower Old Red Sandstone red facies, followed and overstepped by up to $4000 \mathrm{~m}$ of Middle Old Red Sandstone (?Eifelian and Lower Givetian) flags, succeeded in turn by the predominantly fluvial Givetian John o'Groats/Eday Beds. The flags were laid down in an extensive lake basin, the western margin of which can be seen in $S$ and W Caithness but which shows no indication of an eastern margin in either Caithness or Orkney. The John o'Groats/Eday Sandstones are rarely coarse grained or conglomeratic and were laid down by rivers flowing across the infilled Orcadian basin from the S.W. The East Shetland Old Red Sandstone, on the other hand, comprises a very variable sequence of sediments, including thick basal breccias and coarse fluvial conglomerates derived from a mountainous terrain of metamorphic and plutonic rocks to the $W$ and resting on a highly undulating metamorphic basement. This is in contradiction to Storetvedt's reconstruction which implies that the Orcadian basin lay to the $W$. The fish remains indicate that these beds may be of roughly the same age as the John o'Groats/Eday beds, but the presence of species unique to one or other of the areas suggests that the two faunas lived in separate basins.

Shetland contains 3 distinct groups of outcrops of Old Red Sandstone rocks, separated from each other by two major faults: the NNE trending Melby Fault in the W and the $\mathrm{N}$ trending Walls Boundary Fault in the centre of Shetland (Mykura et al., in press; Mykura \& Phemister, in press). West of the Melby Fault the Melby Formation consists of predominantly fluvial sediments derived from the $W$, and apparently overlain by a thick volcanic sequence. The sediments contain two lacustrine fish-bearing horizons, the Melby Fish Beds, the fauna of which can be so closely matched with that of the Sandwick Fish Bed/Achanarras Limestone fauna of the Orcadian basin proper that the fish beds of the 3 areas have been confidently correlated. The close faunal affinities justify the assumption that the Melby Formation may have been deposited along the north-western margin of the Orcadian basin. The Old Red Sandstone rocks between the

Geol. Mag. 112 (1), 1975, pp. 91-94 ). Printed in Great Britain. 
Melby and Walls Boundary Fault comprise the immensely thick $(12000 \mathrm{~m}+)$ Walls Sandstone, the age of which may range from Lower to Low Middle Old Red Sandstone. This sedimentary and volcanic succession has been intruded by a late-Caledonian plutonic complex which was the source of scapolite veins in the sediment; was involved in two major episodes of intense folding; and was intruded by late Caledonian basic and acid dykes. The only other Shetland rocks of similar age, which are locally folded and similarly cut by scapolite veins and basic and acid late-Caledonian dykes, occur in Fair Isle (Mykura, 1972a, b), situated E of the Walls Boundary Fault but some $80 \mathrm{~km}$ farther S. The Old Red Sandstone rocks on Shetland Mainland E of the Walls Boundary Fault have already been described.

The present juxtaposition of 3 groups of Old Red Sandstone rocks in Shetland, which, though resting directly on the metamorphic basement, differ from each other in age, in their depositional and volcanological history and in the extent to which they have been affected by late Caledonian folding, igneous intrusion and scapolitization, leads to the inescapable conclusion that they evolved in completely separate basins and were later brought together by major transcurrent movement along the two faults. Palaeontological evidence from the 3 areas suggests that of the 3 groups, the Melby Formation was nearest to the Orcadian basin and may in fact have been deposited along its margin. Structural, petrographic and mineralogical evidence points to the likelihood that the Walls Sandstone together with the Fair Isle sediments evolved in a more northerly basin. The Old Red Sandstone of E Shetland was probably laid down on the western or north-western margin of the most northerly basin of the three; the probable provenance of the pebbles of its conglomerates, etc., would tend to confirm this. The conclusion drawn from these considerations is that both the Walls Boundary Fault and Melby Fault are major transcurrent faults and that the post- or ?late-Old Red Sandstone movement along them was dextral. Confirmatory evidence for dextral transcurrent movement comes from splay faults of the Walls Boundary Fault and from major Shetland faults which do not cut the Old Red Sandstone, such as the Nesting Fault which according to Miller \& Flinn (1966) has a dextral movement of $12 \mathrm{~km}$.

Though the arguments set out above do, in the writer's opinion, invalidate Storetvedt's hypothesis and palaeogeographic reconstruction, they do not prove late or post Devonian dextral transcurrent movement along the length of the Great Glen Fault, as the direct link-up between the Great Glen Fault and Walls Boundary Fault, though an attractive hypothesis, is as yet unproved. It would thus perhaps be wise to delay further speculation about movement along the fault until a specific investigation of all the relevant land and off-shore data has been carried out.

\section{References}

Garson, M. S. \& Plant, J. 1972. Possible dextral movements on the Great Glen and Minch Faults in Scotland. Nature, Lond. 240, 31-5.

Kennedy, W. Q. 1946. The Great Glen Fault. Q. Jl geol. Soc. Lond. 102, 41-72.

Miller, J. A. \& Flinn, D. 1966. A survey of age relations of Shetland rocks. Geol. $J l \mathbf{5}$, 95-116.

Mykura, W. 1972(a). The Old Red Sandstone sediments of Fair Isle, Shetland Island. Bull. geol. Surv. Gt Br. 41, 1-31.

Mykura, W. 1972(b). Igneous intrusions and mineralization in Fair Isle, Shetland Islands. Bull. geol. Surv. Gt Br. 41, 33-53.

Mykura, W. \& Phemister, (In the press.) The geology of western Shetland. Mem. geol. Surv. Gt Br.

Mykura, W., with contributions by D. Flinn and F. May. (In the press.) British Regional Geology: Orkney and Shetland. I.G.S. Regional Guide.

Munro, M. 1973. Structures in the south-eastern portion of the Strontian granitic complex, Argyllshire. Scott. Jl Geol. 9, 99-108.

Storetvedt, K. M. 1974. A possible large-scale sinistral displacement along the Great Glen Fault in Scotland. Geol. Mag. 111, 23-30. 
Winchester, J. A. 1973. Pattern of regional metamorphism suggests a sinistral displacement of $160 \mathrm{~km}$ along the Great Glen Fault. Nature: Phys. Sci. 246, 81-3.

Institute of Geological Sciences

W. MYKURA

19 Grange Terrace

Edinburgh EH9 2LF

14th February 1974

Published with permission of the Director, Institute of Geological Sciences.

SIR, - Based on stratigraphical and palaeogeographic evidence from the Old Red Sandstone of Shetland and of Caithness, Mykura (above) has taken up certain aspects of my recent paper on the Great Glen transcurrence (Storetvedt, 1974) - he dismisses the idea of a large-scale sinistral displacement, at least along the Walls Boundary Fault, and rather argues in favour of a dextral movement.

Winchester's (1973) recent mapping of the regional metamorphic pattern of central and northern Highlands implies a palaeogeographic reconstruction of Scotland which is in excellent agreement with that obtained from palaeomagnetism (Storetvedt, 1974a). The necessary requirement for having the palaeomagnetic reconstruction in line with that based on metamorphic zonation is that the Great Glen Fault and the Walls Boundary Fault form parts of the same strike-slip fracture. The fact that two independent workers, using entirely different techniques, arrive at a practically identical reconstruction poses a completely new situation in the Great Glen Fault controversy. The combined data of the two studies must be regarded as reasonable evidence for the following two conclusions: (a) there appears to be a direct link-up between the Great Glen Fault and the Walls Boundary Fault and $(b)$ a large-scale sinistral movement seems to have taken place along this fracture zone. It should be made quite clear, however, that my juxtaposition of southern Shetland with Caithness (Storetvedt, 1974) merely corresponds to the minimum displacement which is necessary for removing the palaeomagnetic discordance across the fault. Based on data then available it was impossible to set a reasonable upper limit of the displacement. The same argument applies to Winchester's metamorphic zonation: a further northward movement of NW Scotland along the Walls Boundary Fault would cause no warping in the metamorphic pattern.

The palaeomagnetism of the Devonian volcanics of W Shetland is at present being analysed at this department. The results available so far are extremely interesting in that they indicate that the western parts of the islands have rotated clockwise by at least 20 degrees; i.e. the westward bend in the fault-line which can be followed from $\mathrm{N}$ of Ireland to Shetland also seems to exist in the Norwegian Sea region. However, geophysical evidence (Talwani \& Eldholm, 1972) suggests that immediately $\mathrm{N}$ of Shetland, over a distance of about $200 \mathrm{~km}$, the fault zone curves in a $\mathrm{N}-\mathrm{NE}$ direction. This means that the westward bending of the fault-line as indicated by palaeomagnetism must occur $\mathrm{N}$ of $62^{\circ}$. As sharp discontinuities are unlikly to occur along a major strikeslip fracture one inevitably begins to see the contours of a sinistral shift much in access of $200 \mathrm{~km}$. Further evidence in the same direction comes from a compilation of the gravity field along the continental margin off Norway and northern Britain (cf. Talwani \& Eldholm, 1972, fig. 3). This gravity pattern is dominated by two long anomaly belts: a northern one between $66^{\circ}$ and $69^{\circ}$ passing along and immediately $W$ of the LofotenVesterålen islands and a southern one striking in a north-easterly direction W of Shetland (landward of the shelf edge) and apparently terminating close to the Norwegian coast at $64^{\circ}$. However, a closer inspection of the southern gravity branch indicates a certain discontinuity in its structure at about $62^{\circ}$.S of $62^{\circ}$ the individual anomalies (building up the lineament) exhibit stronger gradients and higher amplitudes than $\mathrm{N}$ of this latitude. In fact the gravity pattern $S$ of $62^{\circ}$ resembles closely that of the Lofoten-Vesterålen structure. Both these more pronounced gravity branches (the Lofoten-Vesterålen one 
in the $\mathrm{N}$ and the one $\mathrm{S}$ of $62^{\circ}$ ) are likely to have their origin in old Precambrian rocks of similar metamorphic chronologies (Talwani \& Eldholm, 1972). The probable trend of the considered fault zone in the Norwegian Sea region makes it reasonable to suspect that the two gravity features concerned (and which are more than $500 \mathrm{~km}$ apart) originally were better lined up and much closer together than at present.

Following the new development in the fault problem of Northern Britain it seems to be a practically impossible task to find corroborative evidence in the Devonian succession exposed on land. Thus, the amount of displacement which according to geophysical evidence may well have been of the order of $500 \mathrm{~km}$ (i.e. a Palaeozoic equivalent to the San Andreas Fault) implies that $E$ Shetland is to be correlated with regions in Invernessshire which are now nearly devoid of Devonian strata. Therefore, it appears to me that Mykura's arguments actually have no direct relevance to the problem under consideration. There appears to be little doubt that further details about the displacement along the Great Glen Fault have to come from geophysics and off-shore geological data.

References (in addition to above)

Storetvedt, K. M. 1974(a). (In the press.) Great Glen Fault. Nature, Lond.

Talwani, M. \& Eldholm, O. 1972. Continental margin off Norway: a geophysical study. Bull geol. Soc. Am. 83, 3575-600.

University of Bergen

KARSTEN M. STORETVEDT

Geophysical Institute

Department of Geomagnetism

Allégt. 70

N-5014 Bergen - Universitetet

Norway

8th May 1974

\section{The assumption of constant volume in the extrapolation of 2-dimensional strain data to 3-dimensions: a discussion of Thakur (1972)}

SIR - The assumption that there is no volume change during deformation is often made in order to simplify tectonic problems, and may be justified in many cases. Recently Thakur (1972) has used this assumption to convert a 2-dimensional strain estimate into a 3-dimensional one.

Assuming constant volume, if two principal strains, $X=1+e_{1}$ and $Y=1+e_{2}$, are known $\left(e_{1} \geqslant e_{2} \geqslant e_{3}\right)$, then the third principal strain $\left(Z=1+e_{3}\right)$ may be calculated, since

For a volume change $\Delta, Z$ is given by

$$
Z=(X Y)^{-1} \text {. }
$$

$$
Z=(1+\Delta)(X Y)^{-1}
$$

$\Delta$ is termed the dilation and, for example, a $10 \%$ volume reduction is expressed as $\Delta=-0.1$.

Let us consider the effect of volume change on Thakur's estimate of $Z$. Firstly we must clear up some confusion in the nomenclature used by Thakur. He states that ' $\lambda_{1}, \lambda_{3}, \lambda_{8}$, represent principal extensions' and uses these symbols in the text as the lengths of the principal axes of the finite strain ellipsoid produced from a unit sphere. Thus his symbols are not the principal quadratic elongations which are usually referred to by $\lambda_{1}, \lambda_{2}, \lambda_{3}$ (Ramsay, 1967; Jaeger, 1969). However, in labelling his Figure 2(b),

Geol. Mag. 112 (1), 1975, pp. 94-96. Printed in Great Britain. 